\title{
Anthós
}

\section{Landslide Susceptibility in Tryon State Park, Oregon}

Tracy E. Handrich

Portland State University

Follow this and additional works at: https://pdxscholar.library.pdx.edu/anthos

Part of the Geology Commons

Let us know how access to this document benefits you.

\section{Recommended Citation}

Handrich, Tracy E. (2011) "Landslide Susceptibility in Tryon State Park, Oregon," Anthós: Vol. 3: Iss. 1, Article 1.

https://doi.org/10.15760/anthos.2011.14

This open access Article is distributed under the terms of the Creative Commons Attribution-NonCommercialShareAlike 4.0 International License (CC BY-NC-SA 4.0). All documents in PDXScholar should meet accessibility standards. If we can make this document more accessible to you, contact our team. 


\title{
Landslide Susceptibility in Tryon State Park, Oregon
}

\author{
Tracy E. Handrich ${ }^{1}$
}

1 Geology Department, Portland State University, P.O. Box 751, Portland, Oregon, 97207

\begin{abstract}
LIDAR and topographic data were used to identify areas of high landslide susceptibility. An arctangent equation was used to calculate slope angle, design criteria of susceptibility and designate zones of high, moderate, and low risk.
\end{abstract}

\section{INTRODUCTION}

A LIDAR image of Tryon State Park, Oregon was analyzed to identify landslide hazards. These data were combined with topographic data of a geologic map in order to investigate the relationship between slope angle and the distribution of landslide features. It was not possible to quantify the effect that substrates of different geology had on overlying sediments, so slope angle was the chief criteria for determining landslide susceptibility. An average slope angle for Tryon State Park obtained and used as the basis for a framework that allowed for the differentiation of areas according to slope steepness, and potential landslide hazard. In determining slope stability, particular attention was paid to areas exhibiting traces of past landslides, channeling, and any evidence of active erosion. The completed map represented a probabilistic model of landslide occurrence, not a deterministic one (Aniya, 1985; Dhakal, S., et al., 1999).

\section{METHODS}

The LIDAR data were examined for features of landslides, primarily scarps and hummocky terrain caused by pressure ridges and landslide toes. Though 9 possible landslides were identified, the morphology of all but 2 landslides were too ambiguous to warrant a 
designation. The map scale for the LIDAR data was in miles, and the smallest increment on the scale was 528 feet, or 160 meters. This distance was used to measure slope because it eliminated potential for error being introduced by an improperly converted map scale, and also provided a high resolution calculation of slope angle that allowed for more precise identification of areas of different steepness.

The average slope of the Tryon State Park was obtained by using an arctangent function (Rockswold, 2006):

$$
\operatorname{Tan}^{-1} \frac{\left(\mathrm{H}_{1}-\mathrm{H}_{2}\right)}{\mathrm{R}}=\Theta
$$

Table 1: Variables in Equation 1.

\begin{tabular}{|l|l|}
\hline$\Theta$ & Slope Angle \\
\hline $\mathrm{H}_{1}$ & Elevation at Slope Peak \\
\hline $\mathrm{H}_{2}$ & Elevation at Slope Base \\
\hline $\mathrm{R}$ & 528 \\
\hline
\end{tabular}

The horizontal distance of the slope, represented by the variable R, was obtained using the LIDAR map scale, with increments of 528 feet. The height of the slope, represented by the expression $\left(\mathrm{H}_{1}-\mathrm{H}_{2}\right)$ represents the difference in elevation between the uppermost index contour of a slope, and the lowest index contour of a slope. The index contour value of 50 feet were used instead of the 18 feet contour intervals because they were more legible and evenly spaced as many of the slopes were within $2-3^{\circ}$ deviation of the average for Tryon State Park.

Seven transects were placed the LIDAR map to measure slope angle (figure 2). The entire horizontal distance of the slope, was used for the $\mathrm{R}$ value in an effort to capture the overall slope 


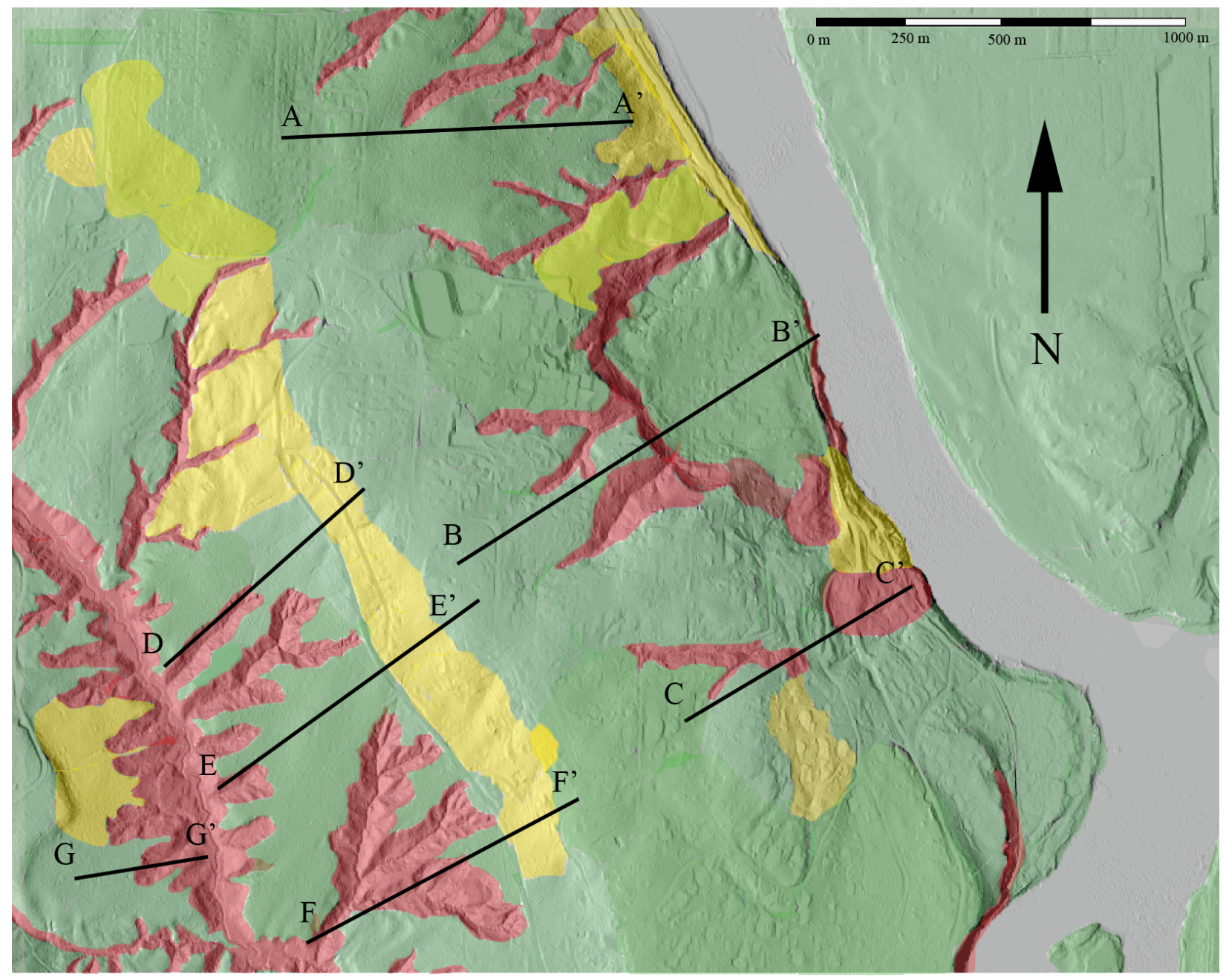

Figure 2: Seven transects were used to measure the slope (A, B, C, D, E, F, G). Each transect represents the horizontal distance of a slope. The points A, B, C, and G represent the slope peak, while A', B', C', and G' represent the slope base. The points D', E', and F' represent slope peak, while D, E, and F represent slope base.

trend. The transects were drawn up on the East and West side of Palatine Hill. Transects A, B, C are located on the East side of Palatine Hill, while transects D, E, F, G are located on the West side. The transects were placed where they were most consistently perpendicular to the contour lines. Transect $\mathrm{G}$ was put in place in an attempt to measure the slope opposite the West side of Palatine Hill. 
Conspicuous erosional features, such as cutbanks and stream channelling, were

categorized as high susceptibility. There were no data available on erosion rates of this area, and this was not able to be taken into consideration when assessing the landslide susceptibility of land situated between two active stream channels (figure 3).

Tryon State Park was found to have relatively uniform and shallow slopes. In order to differentiate Tryon State Park into three zones of landslide susceptibility, very tight criteria were used.

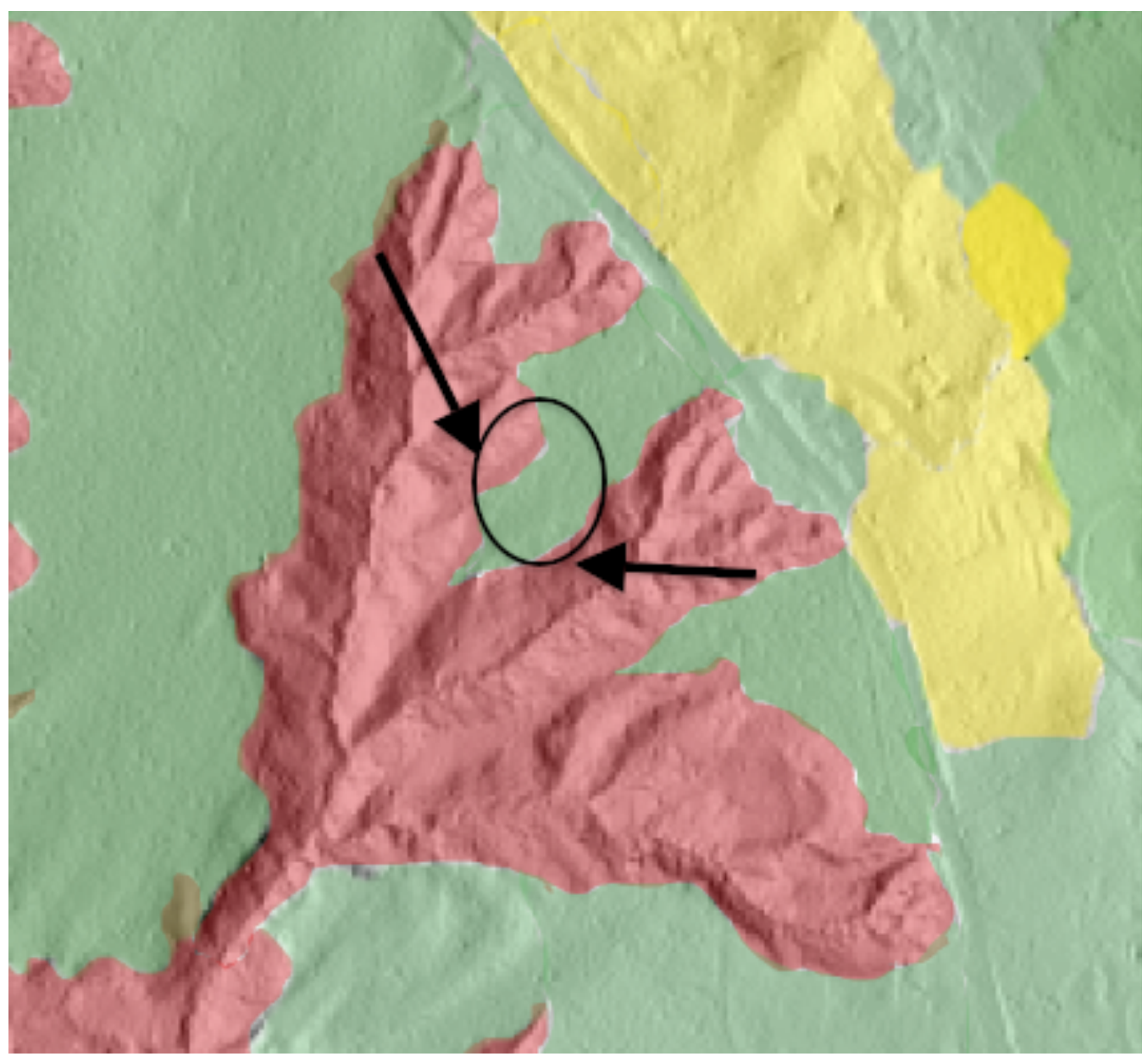

Figure 3: Areas situated between stream channels are jeopardized by erosion. Arrows represent direction of erosion, and the encircled land represents the area that is endangered. Because the endangered area has a slope of less than $10^{\circ}$, it is not susceptible to landslides under the criteria of the hazard map, and the high susceptibility zones (red) do not extend beyond the boundaries of the channels. The map does not take into account erosion rates. 
Given that the smallest increment on the map scale was 160 meters, and that the index contours were in 50 feet increments, it was decided that if a slope had a height less than 100 feet over the distance R of 528 feet, the slope had low susceptibility. Likewise, if the slope height was greater than 100 but less than 150 , over 528 feet, then the slope was deemed moderately susceptible to landslides. If a slope had a height in excess of 150 feet over a distance of 528 feet, then the slope was deemed highly susceptible to landslides.

Table 2: Color designations of landslide risk areas, and their slope angles.

\begin{tabular}{|l|l|l|}
\hline \multicolumn{1}{|c|}{ Color } & \multicolumn{1}{c|}{ Susceptibility } & \multicolumn{1}{c|}{ Slope Angle } \\
\hline Green & Low & $\leq 11^{\circ}$ \\
\hline Yellow & Moderate & $11^{\circ}$ to $16^{\circ}$ \\
\hline Red & High & $>16^{\circ}$ \\
\hline
\end{tabular}

\section{RESULTS}

Table 3: Slope angles were calculated from transects of figure 2 using equation 1.

\begin{tabular}{|l|l|l|l|}
\hline Transect & Horizontal Distance $(\mathrm{m})$ & Vertical Distance $(\mathrm{m})$ & Slope Angle \\
\hline Transect A & 844.91587417703 & 106.681297244574 & $7.19^{\circ}$ \\
\hline Transect B & 965.618141916606 & 121.921482565228 & $7.19^{\circ}$ \\
\hline Transect C & 611.436235064618 & 106.681297244574 & $9.89^{\circ}$ \\
\hline Transect D & 683.979517190929 & 106.681297244574 & $8.86^{\circ}$ \\
\hline Transect E & 844.91587417703 & 106.681297244574 & $7.19^{\circ}$ \\
\hline Transect F & 756.217995610827 & 91.441111923921 & $6.89^{\circ}$ \\
\hline Transect G & 724.213606437454 & 91.441111923921 & $7.19^{\circ}$ \\
\hline
\end{tabular}

The average slope angle for Tryon State Park was found to be $7.82^{\circ}$. 


\section{DISCUSSION}

The susceptibility criteria was too conservative. More elevation data would have allowed for a higher resolution map. The accuracy of the results were constrained by legibility of contour intervals. More data concerning the effects of substrates of different geology on overlying material and landslide susceptibility is effected would have also allowed the map to be more accurate. Tryon State Park is predominantly basalt but applying the susceptibility criteria used in areas of basalt bedrock to areas of alluvial substrate needs to be recalculated with a better understanding of qualities of alluvial substrate.

Cross-platform editing of the data led to certain irremediable compatibility issues during the creation of the hazard map. One such problem was that images were resized between Photoshop CS4 on PC desktops and Apple desktops, and map scales were dilated. At one point an unexpected operating system error caused data loss which was so substantial the map had to be reconstructed from the beginning on a truncated timetable. As a result the margins of areas of differential susceptibility are not identical to the first hazard map.

The criteria of landslide susceptibility presented here needs considerable revision if it is to be applied elsewhere. More data need to be gathered in order to calculate shear stress and better understand effects of saturation and rates of stream channel erosion.

\section{CONCLUSION}

The data suggest that Tryon State Park is relatively insusceptible to landslides, given that the average slope was $7.82^{\circ}$ and the high susceptibility areas had slopes greater than $16^{\circ}$. The most susceptible areas were stream channels, cutbanks, and areas that have been subject to past 
landslides. More data is needed in order to examine the effects of different substrates on

landslide susceptibility of overlying sediment, and to increase the resolution of the map.

APPENDIX

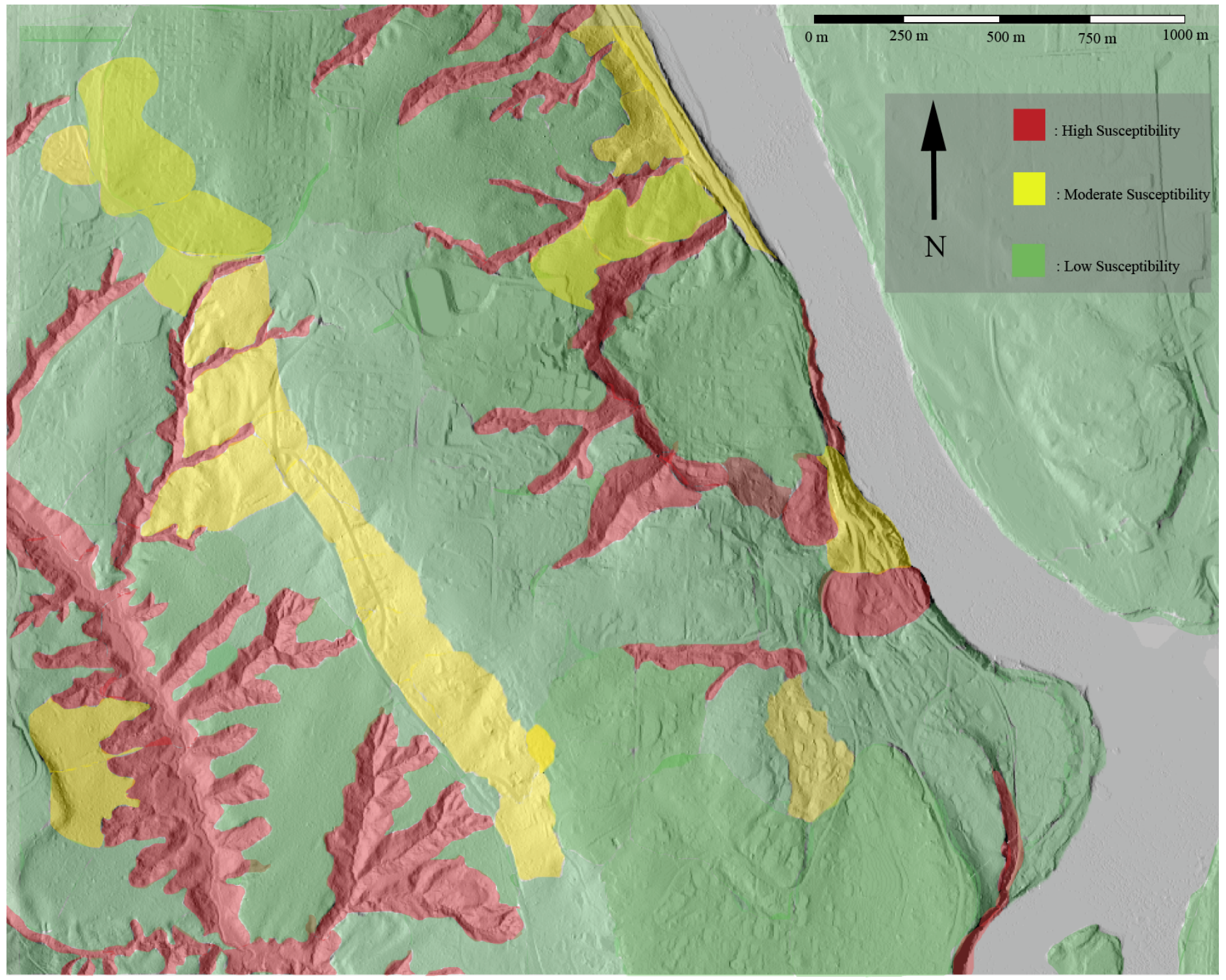




\section{REFERENCES CITED}

\section{Book}

Rockswold, G., 2006, Precalculus: With Modeling and Visualization: Boston, Massachusetts, Addison-Wesley, p. 550-570.

\section{Journal}

Aniya, M., 1985, Landslide-Susceptibility Mapping in Amahata River Basin, Japan: Annals of the Association of American Geographers, v. 75, no. 1, p. 102-113.

Dhakal, S., Amada, T., Aniya, M., 1999, Landslide Hazard Mapping and the Application of GIS in the Kulekhani Watershed, Nepal: Mountain Research and Development, v. 19, no. 1, p. 3-16.

Young, A., Ashford, S., 2006, Application of Airborn LIDAR for Seacliff Volumetric Change and Beach-Sediment Budget Contributions: Journal of Coastal Research, v. 22, no. 2, p. 307-318. 